\title{
Organizational Justice and Organizational Commitment of Public Secondary School Teachers in Cameroon
}

\author{
Kutche Tamghe Chevalier de Dieu \\ School of Management, Panafrican Institute of Development, PO box 35527, Yaoundé-Cameroon \\ * E-mail of the corresponding author: Kutchevalier2002@yahoo.fr
}

\begin{abstract}
This article aims to analyze the impact of organizational justice on the work commitment of public secondary school teachers in Cameroon. To achieve this, we mobilized the theory of social exchange (Blau, 1964, Gouldner, 1960) and opted for a quantitative approach. This was conducted using a random sample of 426 teachers. Thus, the descriptive analysis shows that the level of equity in managerial practices concerning public secondary schools in Cameroon is low. Similarly, the linear regression reveals that distributive justice, procedural justice and interactional justice have a significant influence on teachers' commitment to work. These conclusions were discussed in the perspective of Magner and Johnson (1995) and Chênevert, Charest and Simard (2007) whose results corroborate ours. In contrast, Müller and Djuatio (2011) found no significant link between distributive justice and employee commitment. The results suggest that taking into account equity in HRM practices would improve the level of work commitment of public secondary school teachers in Cameroon.
\end{abstract}

Key-words: HRM practices, organizational justice, work commitment, social exchange, public secondary education

DOI: $10.7176 / \mathrm{JEP} / 10-36-18$

Publication date: December $31^{\text {st }} 2019$

\section{Introduction}

The problematic of the organizational commitment finds its bases in the works of the researchers of the school of the human relations whose principal precursors are: Mayo (1880-1949), Lewin (1890-1947), Maslow (19081970), Mac Gregor (1906-1964), Herzberg (1923-2000) and Likert (1903-1981). They focus on the human factor with the awareness that motivation and organizational commitment are related to the working conditions, the quality of human relations in the company, as well as to the perception of the organizational justice by employees. However, while the question of the link between HRM practices and organizational commitment has become popular among researchers in developed countries since the second half of the 20th century in underdeveloped countries, research on the subject seems to be have not aroused great interest. This is why we are interested in this issue through the study of the link between organizational justice and organizational commitment in the Cameroonian public service and particularly in the national education sector where, notwithstanding the large investments made by the state in this sector, school performance remains mixed or even insufficient (MINESEC, 2015). Indeed, we seem to observe a demotivation of teachers coupled with a disaffection with the profession (RESEN, 2006). However, it is in this sector in Cameroon, that we find the best qualified teachers and a priori the best paid. According to Nji Mfout (2010), the reasons for the decline in the organizational involvement of teachers would be at the level of managerial practices in the education system.

In this study, we will first present the state of the art on organizational justice and organizational commitment by contextualizing them to the education sector in Cameroon. Then we will present the methodology of the study and finally, the results and the discussion.

\section{Review of the literature}

By choosing the organizational justice review for school staff, this study places the human resource at the center of the education and training project. Indeed, there are many works that recognize organizational justice as an essential determinant of workplace attitudes and behaviors (Colquitt, 2001, Müller and Djuatio, 2011, Kutche, 2019). In schools, teachers undergo daily decisions made about them, both in terms of their remuneration and 
their living conditions at work. Generally, in the face of a decision, the teacher will judge in a natural way if the decision is satisfactory for him; but he will also look if it is right.

Historically, distributive justice is the oldest form of organizational justice. The first work on this theme was based on the theory of equity (Adams, 1965) which expresses the perception of justice with regard to the distribution of organizational resources (eg salary, promotions, training). According to Müller and Djuatio (2011), the distributive dimension is based on an assessment of perceived equity. This can be described as a judgment in two stages: in the first, the individual compares his contributions to his benefits obtained what is called "internal equity"; in the second, the individual compares the ratio of internal equity with past experiences and / or solutions proposed by other firms "external equity". In schools, justice is based on the first pillar of the national education strategy, that of "access and equity", and includes fair treatment not only of students but also of employees in the workplace. set of managerial dimensions (MINESEC, 2015). As a general rule, a teacher will perceive his equitable treatment if his remuneration (material, social and symbolic) is proportional to his contributions (effort, performance, time, etc.) in comparison with what he perceives for another reference or a situation. previous (Adams, 1965). In schools, distributive justice can also be translated into equitable access to resources and accountability functions through the rule of equality. Thus, all teachers of the same grade all have the same chances of promotion and the same working conditions. On the other hand, the individual is not only interested in what he receives in terms of rewards but also how they are distributed, which refers to procedural justice.

It was in the mid-1970s that early researchers became interested in procedural justice. It was for them to fill the gaps in distributive justice by emphasizing the correctness of the decision-making process. Müller and Djuatio (2011) believe that procedural justice concerns the methods used by the company to achieve the distribution of organizational resources. Its main indicators are: participation in the decision-making process; participation in the decision; the accessibility of employees to managers; the speed with which employees' problems are dealt with; flexibility (the ability of the company to adapt to the demands of employees). In schools, the materialization of these indicators is done through class councils and department councils. The former are real trading venues where decisions are sovereign and binding on everyone. The department councils for their part are real pedagogical laboratories where programs, pedagogical projects and learning techniques are examined. Each teacher is supposed to contribute freely. According to Piasecki (2017), procedural justice has a major role since, in the event of unfair distributions, it allows these unattractive results to be accepted and the judgment of an unfavorable decision will therefore be more positive if the procedure is fair. To apply procedural justice to the context of teachers, it is necessary to refer to the mechanisms governing the career of teachers, including assignments and promotions, as well as the mechanisms of stimulation. This refers to the special status of the education sector as well as to the internal regulations governing the organization of work in schools. Teachers will constantly question justice in the application of rules and procedures, and their perception will largely depend on their commitment to work. The third form of organizational justice is interactional.

Interactional justice comes in two variants : interpersonal justice and informational justice (Bies and Shapiro, 1988). Interpersonal justice refers to the behavior of colleagues or supervisors towards oneself. Bies and Shapiro (1988) defined several criteria for translating interactional justice. It's about honesty, courtesy, respect for rights and decency of behavior. In schools, the teacher is at the center of the multi-stakeholder relationship, namely: students, parents, colleagues and superiors. The respect and consideration he receives from these different actors in the education system can prove to be a stimulating source of his commitment to work. On the other hand, if the teacher feels despised by the students, the parents, his colleagues and his superiors, his tendency to demotivation will be even greater. The last criterion of fair treatment is the justification of decisions. It is information justice. Bies and Shapiro (1988), as well as Colquitt (2001) have shown that the justification of a decision, or simply the sharing of information by the hierarchy can have an effect on the perception of organizational justice. The teacher will perceive as just the quality of the flow of information between him and the people in charge of the establishment. For this purpose, the justification of the decisions taken by his hierarchy constitutes for him a sign of consideration. Moreover, the association of the teacher with decisionmaking and implementation is an important stimulus for his organizational commitment. In general, in return for the introduction of "right" managerial practices in the school, teachers can develop favorable attitudes, in particular, a greater level of organizational commitment.

Organizational commitment is an employee's commitment to their organization and this psychological state has implications for their decision to remain a member (Meyer and Allen, 1991). According to these authors, three dimensions of organizational commitment can be identified: emotional commitment, calculated and normative. 
Emotional commitment refers to the emotional attachment, identification and commitment of the employee to their organization (Müller and Djuatio, 2011). In our context, teachers with a strong emotional commitment remain the job of desire and not because they have no other choice. This is what leads Nji Mfout (2010) to remind us that if we start from the postulate of the theoretical model of coherence according to which the individual uses his self motivation to choose a profession, we would expect him to as a key word in his career, he gives total commitment. Normative commitment manifests itself in attitudes of loyalty and duty. It reflects a predisposition to act in the interests of the organization. A teacher carried by a normative commitment will be sensitive to the rules, will respect them, even if he does not share them. He remains in the profession by duty, by obligation. The calculated commitment or commitment to continuity, highlights the cost generated by the departure of the organization. Employees with a strong calculated commitment remain in the organization as needed and may eventually experience frustrations that could make their work unsuitable (Meyer and Allen, 1991). Teachers with a strong calculated commitment feel very quickly frustrated when their needs are not met.

According to Ping Wang (2011), commitment is like vigor, dedication and concentration at work. It seems linked to increased productivity and a lower turnover rate. Many concepts used in organizational behavior are similar to engagement, including motivation, engagement, commitment, commitment to organization, initiative, and loyalty. For Peretti, Pozzo Di Borgo, Barth, Brunet et al. (2012). there can be no commitment without a real appropriation of the collective project communicated by the management team which is also called "the Meaning". To mobilize each employee, he must listen to it, ensure its autonomy, allow him to express what is "worth for him" while being part of the values of the company. Thus, human resources management and internal communication tools must, according to him, make it possible to measure this commitment of employees in order to make it a real lever of social performance. As for Roussel, Dalmas and Oubrayrie-Roussel (2009), they find that employee engagement is highly valued by contemporary organizations in that a simple compliance with formal requirements does not make it possible to survive in a very dynamic competitive context. According to Simard and Lapalme (2003), the possible targets of the organizational commitment are multiple It can be the strategy of the organization, its organizational structure, the profession, the team, the immediate superior, the managerial practices.

Inspired by the postulate of Meyer and Allen (1991), a teacher will be said committed if he is dedicated and focused in his work and if his intention to start in case of better opportunity is not great. According to Nji Mfout (2010, Kutche, 2019), we note a teacher not engaged by his lack of interest in school and extracurricular activities, the lack of additional efforts to address the learning needs of learners, the non-preparation of classes and the willingness to leave at the slightest opportunity. Finally, a committed teacher gets involved and is happy to do it. He is happy to be a member of the organization for which he works and does everything in his power to remain so (Meyer and Allen, 1991).

The link between organizational justice and organizational commitment can be explained from the theory of social exchange. Contrary to economic exchange based on an explicit contract and indicating the rights and obligations of the parties, the theory of social exchange (Blau 1964, Gouldner 1960) refers to an exchange relationship in which parts are not specified. Social exchange is "the voluntary acts of individuals motivated by the returns that these acts are supposed to bring and that they actually bring on the part of others" (Blau, 1964). Contextualizing this theory to the world of work, social exchange then apprehends the employment relationship as an exchange between the employer and the employee and identifies different types of "social exchange", a function of the partner and coexisting within the family. 'organization. Indeed, being able to be approached from the point of view of the relation between two groups of individuals like the representatives of the personnel and the leaders, the social exchange also considers the relations between two individuals, like the employee and his manager, or between an individual and a group such as the employee and the organization (Quenneville, 2007).

The theory of social exchange is used as the dominant conceptualization to study the employee-organization relationship (Shore and Coyle-Shapiro, 2003). Flagship conception of organizational literature, the theory of social exchange is inspired by the anthropological work of Mauss (Mauss, 1924), which, transposed to contemporary societies, today specify the motivational bases of employee attitudes and behaviors.

Described by Blau (1964) as "voluntary acts of individuals motivated by the returns that these acts are supposed to bring and that they actually bring on the part of others" social exchange implies a reciprocity based subsequently on three fundamental principles : investment, trust and commitment. The basic principles 
underlying this conception can be summarized as follows: (1) an individual who renders a useful service to another individual places him in a position of accountability and (2) in order to fulfill this obligation the second individual will provide in return benefits to the first individual (Quenneville, 2007).

Blau (1964) used the work of Homans (1961) to classify exchange relations into two categories : economic and social. Economic exchange can be defined as a pre-determined exchange, in which a formal contract is used to ensure that each party is subject to its obligations. The so-called "social" exchange entails for individuals a more diffuse obligation, not integrated within a previously concluded market and paid at the discretion of both parties. Mauss (1924) already referred to this type of exchange by mentioning that the wealth transmitted between the parties is integrated within a much more global and permanent contract. Economic and social exchanges are therefore determined according to Blau (1964) by the nature of the obligations felt and by the moment when the two parties decide to settle their respective debts. The social exchange as defined by Blau (1964) includes only voluntary actions by individuals "motivated by the rewards they should bring, and in fact they entail on the part of others" (Blau, 1964). In addition, it excludes actions carried out under the constraint of force, those responding to the imperative suggestions of the passions or only the injunctions of collective prescriptions. According to him, exchange relations also involve the exchange of tangible or intangible benefits. On the other hand, only social exchange can give way to feelings of obligation that lead employees to exchange intangible benefits such as consideration and loyalty. It postulates that interhuman relations are animated by "forces of attraction between individuals", by an endogenous movement, sui generis, towards others, which leads to the fact that interpersonal links can be established by having their own existence as a reason to be and finality.

In a social exchange relationship, individuals are also interested in maintaining a balance between their investments and the benefits received so as not to feel indebted to the other party (Kutche, 2019). Social exchange then implies the existence of a will of reciprocity which creates a constraint towards equilibrium by reducing the feeling of debt felt by the parties involved. This desire for reciprocity serves as a starting mechanism for social interactions.

Indeed, by observing the processes of reciprocity inherent in the exchange and involving at least two persons or entities in a relationship, Blau (1964) deduces that these voluntary acts, these "gifts", impose a form of investment in the relationship, regardless of their tangible characteristics, such as loan, training or salary increase, or abstract, like the simple advice or psychological support. This perception of the donation-based exchange is also supported by Eisenberger et al. (2002). According to Alter (2012), to mobilize the theory of giving (Mauss, 1923) to analyze labor relations may seem paradoxical but understandable: the enterprise is generally conceived as a place of profit, utilitarian calculus, praxis of standard economic theory. For him, however, this paradox only applies if the theory of giving is confused with a theory of altruism, whereas it is, more broadly, a theory of social exchange, which integrates the question of interest, and violence. This paradox is also valid only if we believe that the standard economic theory perfectly reflects the practices of the actors, whereas most of the observations made by the sociology of the world of work show that the efficiency of the firm supposes a capacity to cooperate, and that cooperation is always a social exchange (Alter, 2012).

Moreover, and if the social exchange results from "favors which create diffuse future obligations, not precisely specified, and whose nature of the counterpart can not be negotiated but must be left to the discretion of its author" (Blau, 1964), this process of reciprocity requires trust and mutual commitment between the partners, thus ensuring this "implicit obligation to give back". This sequence of transactions, based on interdependent and sequential interactions between two parties and motivated by a self-reinforcing process, then builds a highquality exchange relationship where the exchanged favors and obligations of both partners symbolize loyalty and mutual support as well as goodwill and personal investment (Cropanzano and Mitchell, 2005).

Thus, the equitable actions of the organization and / or the superior inspire in the employee a feeling of obligation which favors functional behaviors on his part (Cropanzano and Mittchel, 2005), observing notably through the concept of support perceived organizational impact.

Some theories developed about exchange relations imply that the main motivation of individuals to return the benefits they receive is related to the satisfaction of their individual interests. In this sense, Homans (1961) states that the parties involved in an exchange of material goods seek equivalence in their contributions and the maximization of their profit. Adams (1965) also agrees in this direction by mentioning that individuals, in 
comparing each other, seek equity in their exchange relationship. Overall, these fundamentally economic models suggest that individuals are inclined to contribute to the relationship only in cases where it involves equitable trade. On the other hand, the sociologist Mauss (1924) is of the opinion that exchange relations are not limited to the maximization of personal gains. In fact, it states that by reducing trade to an instrumental means of satisfying individual interests, relations considered from an economic point of view are reductionist and omit certain moral principles. In fact, according to his observations, donations exchanged may also be of a moral character, closely related to the values and beliefs of a given group of individuals. From this point of view, research related to organizational behavior generally supports the idea that the process that governs social exchange is the moral obligation felt when an individual is in a debt position (Eisenbenger et al., 2001). In this sense, Mauss (1924) specifies in his research that an exchanged gift generates a sense of obligation to return the benefit to the recipient. Moreover, it emphasizes that this obligation can paradoxically be considered as a constraint and that, in these circumstances, exchanges are less popular.

From this perspective, the underlying process of social exchange is not reduced to the sole intention of satisfying one's own interests and optimizing one's privileges. Thus, arguing that social exchange is based on a universal moral standard, Gouldner (1960) was one of the first to denounce this approach. According to his theory, the foundations of social exchange are based on moral principles that go beyond a simple cost / benefit calculation (Quenneville, 2007). In this way, social exchange is then based on a standard of reciprocity that compels individuals to respond positively to favorable treatment received from others. The standard of reciprocity implies the development of a universal moral obligation acting as the starting mechanism for a beneficial exchange between two parties. More specifically, this standard of reciprocity refers to two principles: 1) individuals should help those who helped them, and 2) individuals should not hurt those who helped them. According to Gouldner (1960), the stability of social systems depends on this norm of reciprocity which generates a quota exchange of gratification.

In the school context, teachers are interested in maintaining a balance between their investments and the benefits received so as not to feel indebted to the other party. In this case, the exchange would then involve the existence of a will of reciprocity which creates a constraint towards equilibrium by reducing the feeling of debt felt by the parties involved (Gouldner, 1960). Therefore, the organizational commitment of the teacher will depend on the perception he has of the consideration that his organization has of his person and his work. For example, Müller and Djuatio (2011) used this theory to predict the effects of organizational justice on satisfaction and organizational commitment. Their results showed that taking into account the perception of justice in managerial practices had an effect on employee satisfaction. Thus, the theory of social exchange provides arguments to understand why some employees are motivated in relation to others to help their organization achieve its goals. As a result, the theory could provide elements of understanding of the various attitudes of teachers, all civil servants and working in the same educational system.

With the above developments, we want to know if organizational justice influences the organizational commitment of teachers in public secondary education in Cameroon. More precisely, we want to measure the effect of the different forms of organizational justice : distributive, procedural and interactional on the organizational commitment of public secondary school teachers in Cameroon. For this, we formulate the following general hypothesis: (HG) Organizational justice influences the commitment of public secondary school teachers in Cameroon. This hypothesis is divided into three research hypotheses that are :

a) Distributive justice influence the organizational commitment of teachers in secondary public in Cameroon

b) Procedural justice has an effect on the organizational commitment of teachers in public secondary schools in Cameroon

c) Interactional justice has an influence on the organizational commitment of teachers in secondary public in Cameroon 


\section{Methodology}

Our methodology approach is based on quantitative research. Data collection was carried out among public secondary school teachers in the cities of Douala, Yaoundé and Bafoussam $(\mathrm{N}=426)$. Participants were contacted individually. The study was presented to them as academic research to improve understanding of the factors of teachers' organizational commitment. To ensure confidentiality, the questionnaire was given to the participant in a folder, each one having one day to answer it. The average age of respondents is 34 , while $56 \%$ of participants are female. In terms of work experience, more than $60 \%$ of the respondents have at least five years of experience as a teacher. Also, the vast majority of teachers (292) have a DIPES II while 134 have a DIPES I. Given the linguistic diversity of Cameroon (French and English), where both formations in the subsystems Francophone and Anglophone, we respected the absolute parity between these two subsystems, namely $50 \%$ of teachers for each of the two subsystems.

To arrive at the test of our hypotheses, we have previously analyzed the frequencies of all our variables. For this purpose, their items were measured on a 5-way Likert scale, ranging from 1 (strongly disagree) to 5 (strongly agree). This allowed us to appreciate the level of perception of organizational justice by teachers in public secondary schools in Cameroon as well as their level of organizational commitment. We considered unfair or unfair managerial practices whose average opinion is below modality 3 representing neutral or undecided opinion on the Likert scale. The same procedure is applied for the organizational commitment variable. Then we made sure of the quality and reliability of our measuring instruments. These have been done through the Factorial Analysis of Multiple Correspondences (AFCM). We have retained as coherent the scales indicating an Alpha of Cronbach $(\alpha)$ greater than 0.6. The factors considered valid are those whose percentage of the average variance presented is at least $50 \%$. In general, the scales have shown satisfactory psychometric qualities, although the level of implementation of organizational justice in the Cameroonian education system, as well as the level of organizational commitment of teachers are quite low.

The measure of the perception of distributive justice is inspired by the Colquitt (2001) scale called the Organizational Justice Scale (OJS). Examples of items : "Your salary proportional to your work", "The distribution of premiums is fair" (Average frequency $=2.66$, Alpha of Cronbach $\alpha=0.80$, Average variance presented $=63.21 \%)$.

To measure the perception of procedural justice, we used the Naumann and Benett (2000) scale. Examples of items : "The decisions made by our superiors respect the rules and procedures consistent", "the special status of teachers is respected" (Average frequency $=2.67$, Alpha of Cronbach $\alpha=0.91$, average variance presented $=$ $57.80 \%)$.

In terms of interactional justice, we have borrowed and adapted the Colquitt scale (2001) to assess the quality of relationships with superiors. Examples of items : "In general, our superiors treat us with respect", "Our superiors explain the reasons for their decisions" (Average frequency $=3.13$, Alpha of Cronbach $\alpha=0.91$, Average variance presented $=79.31$ )

Organizational commitment is measured using four items inspired by Kutche (2019), Mowday, Steers and Porter (1979). Example of items : "If it is necessary for my school, I agree to supervise the pupils outside the usual hours", "I recommend without hesitation to my students, the profession of teacher" (Average frequency $=2.70$, Alpha of Cronbach $\alpha=0.72$, average of the variance presented $=54.80$ ).

\section{Results of the study}

The results of the distributive justice regression tests on organizational commitment are presented in the following tables. Table 1 indicates a correlation coefficient $\mathrm{R}$ of 0.76 , which means that the two variables are significantly related. The coefficient of determination $\mathrm{R}^{2}$ is 0.59 , which is a contribution of distributive justice to the explanation of the variability of the organizational commitment of 59\%. It can therefore be said that the predictive power of distributive justice over the organizational commitment of teachers is average. The variation of $\mathrm{F}$ is very positive (455.86) and very significant with p-value $<0.001$, and seems to support this prediction. Finally, residue analysis through the Durbin-Watson test (1.84) shows that for the regression model, the residues 
appear to follow a regression line. However, it is useful to analyze the parameters of the regression model to verify the quality of the link between the two variables.

Table 1 : Summary of distributive justice regression model on teachers organizational commitment

Model Summaryb

\begin{tabular}{|c|c|c|c|c|c|c|c|c|c|c|}
\hline \multirow[b]{2}{*}{ Model } & \multirow[b]{2}{*}{$\mathrm{R}$} & \multirow[b]{2}{*}{ R Square } & \multirow[b]{2}{*}{$\begin{array}{l}\text { Adjusted } \\
\text { R square }\end{array}$} & \multirow[b]{2}{*}{$\begin{array}{l}\text { Std Error of } \\
\text { the Estimate }\end{array}$} & \multicolumn{5}{|c|}{ Change Statistiques } & \multirow[t]{2}{*}{$\begin{array}{l}\text { Durbin- } \\
\text { Watson }\end{array}$} \\
\hline & & & & & $\begin{array}{l}\text { R Square } \\
\text { Change }\end{array}$ & $\begin{array}{c}\mathrm{F} \\
\text { Change }\end{array}$ & $\mathrm{d} 11$ & $\mathrm{~d} 12$ & $\begin{array}{l}\text { Sig. F } \\
\text { Change }\end{array}$ & \\
\hline 1 &, $720^{\mathrm{a}}$ & ,518 &, 517 & 36343 & ,518 & 455,860 & 1 & 424 &, 000 & 1,841 \\
\hline
\end{tabular}

a. Predictors : (Constant), Distributive Justice

b. Dependant Variable : Organizational Commitment

Analysis of the model parameters (Table 2) shows that distributive justice has a positive and very significant effect on teacher engagement with a very interesting Beta $\beta=0.76$, a t of Student $t=24.69$ and a very significant $\mathrm{p}$-value $\mathrm{p}<0.001)$. Therefore, we can reject the hypothesis that the relationship found in the sample is due to chance. On the basis of these results, hypothesis 1 that distributive justice influences the commitment of public secondary school teachers in Cameroon is verified.

Table 2 : Parameters of the distributive justice regression model on teachers organizational commitment

Coefficients ${ }^{\mathbf{a}}$

\begin{tabular}{|ll|c|c|c|c|c|c|c|}
\hline \multirow{2}{*}{ Model } & \multicolumn{2}{|c|}{$\begin{array}{c}\text { Unstandardized } \\
\text { Coefficients }\end{array}$} & \multirow{2}{*}{$\begin{array}{c}\text { Standardized } \\
\text { Coefficients }\end{array}$} & \multirow{2}{*}{ Sig. } & \multicolumn{2}{|c|}{ Collinearity Statistics } \\
\cline { 2 - 6 } & B & Std Error & Beta & & & Tolerance & VIF \\
\hline 1 & (Constant) &, 658 &, 097 & & 6,765 &, 000 & & \\
& Distributive justice &, 767 &, 036 &, 720 & 21,351 &, 000 & 1,000 & 1,000 \\
\hline
\end{tabular}

a. Dependant Variable : Organiqational Commitment

Tables 3 and 4 present the results of the regression analysis of procedural justice on organizational engagement. As can be seen in Table 3, the coefficient of determination $\mathrm{R}^{2}$ is 0.65 , which is a contribution of procedural justice to the explanation of the variability of the organizational commitment of $65 \%$. The predictive power of procedural justice over the organizational commitment of teachers is strong. The variation of $F$ very positive (788.83) and very significant with p-value $<0.001$ seems to confirm this prediction. The Durbin-Watson test shows a result of 1.74 and indicates that for the regression model, the residuals seem to follow a regression line. However, it is useful to analyze the parameters of the model to check the quality of this regression.

Table 3 : Summary of procedural justice regression model on teachers organizational commitment

\begin{tabular}{|c|c|c|c|c|c|c|c|c|c|c|}
\hline \multirow[b]{3}{*}{ Model } & \multicolumn{9}{|c|}{ Model Summary ${ }^{\text {b }}$} & \multirow[b]{3}{*}{$\begin{array}{l}\text { Durbin- } \\
\text { Watson }\end{array}$} \\
\hline & \multirow[b]{2}{*}{$\mathrm{R}$} & \multirow[b]{2}{*}{$\begin{array}{c}\mathrm{R} \\
\text { Square }\end{array}$} & \multirow[b]{2}{*}{$\begin{array}{l}\text { Adjusted } \\
\text { R square }\end{array}$} & \multirow[b]{2}{*}{$\begin{array}{l}\text { Std Error of } \\
\text { the Estimate }\end{array}$} & \multicolumn{5}{|c|}{ Change Statistiques } & \\
\hline & & & & & $\begin{array}{l}\text { R Square } \\
\text { Change }\end{array}$ & F Change & dl1 & $\mathrm{d} 12$ & $\begin{array}{c}\text { Sig. F } \\
\text { Change }\end{array}$ & \\
\hline 1 & $806^{\mathrm{a}}$ &, 650 &, 650 & ,30955 &, 650 & 788,838 & 1 & 424 &, 000 & 1,784 \\
\hline
\end{tabular}

a. Predictors: (Constant), Procédural Justice

b. Dependant Variable : Organizational Commitment

The analysis of the model parameters (Table 4) shows that the regression coefficient Beta is very interesting $\beta=$ 0.80 , with a Student's $t \mathrm{t}=28.02$ and a very significant $\mathrm{p}$-value $\mathrm{p}<0.001$. Therefore, we can reject the hypothesis that the relationship found in the sample is due to chance. Hypothesis 2 that procedural justice has an effect on the commitment of public secondary school teachers in Cameroon is verified. 
Table 4 : Parameters of the procedural justice regression models on teachers organizational commitment

\section{Coefficients ${ }^{\mathbf{a}}$}

\begin{tabular}{|c|c|c|c|c|c|c|c|}
\hline \multirow[b]{2}{*}{ Model } & \multicolumn{2}{|c|}{$\begin{array}{c}\text { Unstandardized } \\
\text { Coefficients }\end{array}$} & $\begin{array}{l}\text { Standardized } \\
\text { Coefficients }\end{array}$ & \multirow{2}{*}{$\mathrm{t}$} & \multirow{2}{*}{ Sig. } & \multicolumn{2}{|c|}{ Collinearity Statistics } \\
\hline & $\mathrm{B}$ & Std Error & Beta & & & Tolerance & VIF \\
\hline $1 \quad$ (Constant) & 220 &, 090 & & 2,458 &, 014 & & \\
\hline Procédural Justice & ,926 & 033 &, 806 & 28,086 &, 000 & 1,000 & 1,000 \\
\hline
\end{tabular}

a. Dependant Variable : Organizational Commitment

Tables 5 and 6 concern the regression of interactional justice on organizational commitment. Table 5 shows that the coefficient of determination $\mathrm{R}^{2}$ is 0.55 , ie a contribution of interactional justice to the explanation of the variability of the organizational commitment of $55 \%$. The predictive power of interactional justice over teacher engagement is average. The variation of $\mathrm{F}$ is very positive (521.18) and very significant with p-value $<0.001$, and seems to support this prediction. Finally, residue analysis through the Durbin-Watson test (1.82) shows that for the regression model, the residues appear to follow a regression line. The analysis of the model parameters is necessary to check the quality of this regression.

Table 5 : Summary of interactional justice regression models on teachers organizational commitment

\begin{tabular}{|c|c|c|c|c|c|c|c|c|c|c|}
\hline \multirow[b]{3}{*}{ Model } & \multirow[b]{3}{*}{$\mathrm{R}$} & \multicolumn{8}{|c|}{ Model Summary $^{\mathbf{b}}$} & \multirow[b]{3}{*}{$\begin{array}{l}\text { Durbin- } \\
\text { Watson }\end{array}$} \\
\hline & & & & & \multicolumn{5}{|c|}{ Change Statistiques } & \\
\hline & & $\begin{array}{c}\mathrm{R} \\
\text { Square }\end{array}$ & $\begin{array}{l}\text { Adjusted } \\
\text { R square }\end{array}$ & $\begin{array}{l}\text { Std Error of } \\
\text { the Estimate }\end{array}$ & $\begin{array}{l}\text { R Square } \\
\text { Change }\end{array}$ & F Change & $\mathrm{d} 11$ & $\mathrm{~d} 12$ & $\begin{array}{c}\text { Sig. F } \\
\text { Change }\end{array}$ & \\
\hline 1 &, $743^{\mathrm{a}}$ &, 551 &, 550 &, 35065 &, 551 & 521,187 & 1 & 424 &, 000 & 1,821 \\
\hline
\end{tabular}

a. Predictors : (Constante), Interactional Justice

b. Dependant Variable : Organizational Commitment

Table 6 shows that interactional justice has a positive and very significant effect on teacher engagement with a very interesting Beta $\beta=0.74$, a $t$ of Student $t=22.83$ and a very significant $p$-value $p<0.001$ ). Therefore, we can reject the hypothesis that the relationship found in the sample is due to chance. Thus, hypothesis 3 that interactional justice has an influence on the engagement of public secondary school teachers in Cameroon is verified.

Table 6 : Parameters of the interactional justice regression model on the organizational commitment of teachers Coefficients $^{\mathbf{a}}$

\begin{tabular}{|ll|c|c|c|c|c|c|c|}
\hline \multirow{2}{*}{ Model } & \multicolumn{2}{|c|}{$\begin{array}{c}\text { Unstandardized } \\
\text { Coefficients }\end{array}$} & $\begin{array}{c}\text { Standardized } \\
\text { Coefficients }\end{array}$ & $\mathrm{t}$ & Sig. & \multicolumn{2}{c|}{ Collinearity Statistics } \\
\cline { 2 - 10 } & $\mathrm{B}$ & Std Error & Beta & & & \multicolumn{2}{|c|}{ Tolerance } & VIF \\
\hline 1 & (Constant) &, 582 &, 094 & & 6,168 &, 000 & & \\
& Interactional justice &, 789 &, 035 &, 743 & 22,830 &, 000 & 1,000 & 1,000 \\
\hline
\end{tabular}

a. Dependant Variable : Organizational commitment

\section{Discussion}

Our study aimed to verify the influence of organizational justice on the organizational commitment of public secondary school teachers in Cameroon. The validation of our three research hypotheses led us to the total validation of the general hypothesis according to which organizational justice influences the commitment of public secondary school teachers in Cameroon. In addition, the regression analysis found that this influence is not only positive but very significant. This means that more equitable HRM practices would substantially improve their organizational commitment. Procedural justice seems to have the most significant effect on teachers' organizational commitment $(\beta=0.80)$, followed by interactional justice $(\beta=0.74)$ and distributive justice $(\beta=0.72)$.

These results corroborate those of Magner and Johnson (1995) who, in a survey of 277 municipal police chiefs, observed a continuation of the positive effect of procedural justice on organizational commitment. Similarly, in 
their meta-analysis of 190 studies, Cohen-Charash and Spector (2001) conclude that emotional engagement is significantly more related to procedural justice than to distributive justice or interactional justice. Chênevert, Charest and Simard (2007), for their part, conducted a study of 80 employees in a health facility in Quebec and their results also show that the emotional commitment increases with the perception of procedural justice. More recently, Müller and Djuatio (2011) have shown through a survey of 352 employees that procedural justice has a very significant effect on engagement. On the other hand, they found no significant link between distributive justice and commitment.

In general, each form of organizational justice positively affects emotional engagement. In the theoretical perspective of social exchange, this means that employees who perceive that the results, procedures and application of these are equitable will have an emotional attachment to the organization or the superior due to the effect of the standard of reciprocity. These results suggest that teachers who perceive that their fees, as well as the procedures and their application are fair, will have a strong emotional attachment to the institution. In addition, teachers seem to be very sensitive to the quality of the social relations maintained with the different stakeholders of the education system and in particular, the school leaders. A negative perception of these relationships could deteriorate their emotional commitment and work climate. In general, our results, corroborating those of most authors cited, argue in favor of improving teacher engagement through more just and equitable management practices. The differences in results observed would result from the nature of the samples and the study sector, most of these studies being conducted in for-profit companies whose purpose is not the same as public schools that have a vocation. rather social and public service.

\section{Conclusion}

The objective of this research was to test the hypothesis that organizational justice determines the organizational commitment of teachers in public secondary school in Cameroon. Quantitative analysis has revealed that public secondary school teachers seem to perceive managerial practices that concern them as not being sufficiently accurate. Also, we have noticed that their level of commitment is quite low. To test our hypothesis, we performed simple linear regression analyzes that showed a positive and significant influence of organizational justice on the organizational commitment of teachers.

Our research enriches current knowledge on organizational justice applied to public structures to public nonprofit structures such as schools. By our results, school heads and in particular the State which is the employer of the teachers, have every interest in worrying about the perception of the organizational justice by the latter if they wish to improve significantly their organizational commitment and hence the school performance. It would be particularly useful to focus on procedural issues, including respect for the special status of the national education body, as well as a more transparent, objective and equitable retribution, promotion and assignment policy.

Despite the contributions of this study, there are a number of limitations that deserve to be noted: We have not taken into consideration the temporary teachers and the support staff who are very numerous in high schools and are concerned by managerial practices at the local level. These limits open avenues of research for future studies that could incorporate moderator or mediator variables. The study of the impact of organizational justice on the satisfaction and turnover of teachers are other avenues for research to explore.

\section{References}

Adams, J.S. (1965). Inequity in social exchange. In Berkowitz, L, Advances in Experimental social psychology, 2, 267-299. New York: Academic Press.

Alter, N. (2012). Don et échange social. In Norbert Alter éd., Sociologie du monde du travail (p. 139-158). Paris cedex 14, France, PUF. doi: 10.3917/puf.alter.2012.01.0139.

Bies, R. J. et Shapiro, D. L. (1988). Voice and justification: Their influence on procedural fairness judgments. Academy of Management Journal, 31(3), 676-685.

Blau, P.M. (1964). Exchange and power in social life. New York, John Wiley, 352 p.

Chênevert, D., Charest, A. et Simard, G. (2007). Étude de l'évolution des déterminants de l'engagement affectif: le rôle de l'habilitation, du plafonnement de carrière et de la justice organisationnelle. Relations industrielles, 62(2) 258-281. 
Colquitt, J.A. (2001). On the Dimensionality of Organizational Justice: A Construct Validation of a Measure. Journal of Applied Psychology, 86(3), 386-400.

Cropanzano, R. et Mitchell, M.S. (2005). Social exchange theory: an interdisciplinary review. Journal of Management, 31(6) 874-900.

Eisenberger, R., Stinglhamber, F., Vandenberghe, C., Sucharski, et Rhoades, L. (2002). Perceived Supervisor Support: Contributions to Perceived Organizational Support and Employee Retention. Journal of Applied Psychology, 87, 565-573

Gouldner, A. (1960). The norm of reciprocity A preliminary statement. American Sociological Review, 25(2), 161-178. doi10.2307/2092623.

Homans, G.C. (1961). Social Behaviour: Its Elementary Forms. New York: Harcourt Brace et World, 386p.

Kutche, T.C.D. (2019). Pratiques de GRH et performance sociale dans les établissements du secondaire public au cameroun. Thèse de doctorat en GRH, IPD-AC, $324 \mathrm{p}$.

Kutche, T.C.D. et Essomme, I. (2019). Les effets du développement des ressources humaines sur la performance sociale des enseignants du secondaire public au Cameroun. Journée de Recherche de l'ENS de Bertoua, 6 décembre 2019, $17 \mathrm{p}$.

Magner, N., Johnson, G., Little, H., Blair Staley, A. et Welker, R. (2006). The case for fair budgetary procedures. Managerial Auditing Journal, 21(4), 408-419. https://doi.org/10.1108/02686900610661414

Mauss, M. (1923-1924). Essai sur le don: Forme et raison de l'échange dans les sociétés archaïques. L'Année Sociologique, 1, (2), 30-186.

Meyer, J.P. et Allen, J.N. (1991). Three component conceptualizations of organizational commitment. Human Resource Management Review, 1(1), 61-89. https://doi.org/10.1016/1053-4822(91)90011-Z.

MINESEC. (2015). Analysis report of statistical data of MINESEC, 2014-2015, 203 p.

Mowday, R., Steers, R. et Porter, L. (1979). The measurement of organizational commitment. Journal of Vocational Behavior, 14, 224-227.

Müller, J. et Djuatio, E. (2011). Les relations entre la justice organisationnelle, l'employabilité, la satisfaction et l'engagement organisationnel des salariés. Revue de gestion des ressources humaines, 82(4) 46-62. doi:10.3917/grhu.082.0046.

Naumann, S.E. et Bennett, N. (2000), A case for procedural justice climate: Development and test of a multilevel model. Academy of Management Journal, 43, 881-889.

Nji, Mfout, A.F. (2010). L'épanouissement de l'enseignant et son engagement organizational: cas des enseignants de quelques établissements de Yaoundé. Mémoire de Master en psychologie sociale, Université de Yaoundé I, $111 \mathrm{p}$.

Peretti, J.M., Pozzo Di Borgo, P., Barth, I., Brunet, S. et al. (2012). Regards croisés sur l'engagement. Comment obtenir l'engagement des salariés en 2013? Question(s) de management, 2(1), 119-137. doi: $10.3917 / \mathrm{qdm} .122 .0119$

Piasecki. C. (2017). L'utilisation de la justice organisationnelle dans une démarche de prévention des risques psychosociaux. Thèse de doctorat, Université Côte d'Azur, 348p.

Quenneville, N. (2007). L'échange social dans les relations au travail. Trois études sur les comportements citoyens des employés. Thèse de doctorat, Université du Québec à Montréal, $199 \mathrm{P}$.

Roussel, P., Dalmas, M. et Oubrayrie-Roussel, N. (2009). Les modèles intégrateurs de la motivation au travail. In Rojot, J., Roussel, P. et Vandenberghe, C. Comportement Organisationnel, 3(6), 235-249.

Shore, L.M. et Coyle-Shapiro, J.A-M. (2003). New developments in the employee organization relationship. Journal of Organizational Behavior, 24, 443-450.

Simard, G. et Lapalme, M.E. (2003). Mobiliser les ressources humaines: le rôle des comportements discrétionnaires. Dans R. Foucher, A. Savoie et L. Brunet (Eds.), Concilier la performance organisationnelle et santé psychologique au travail (pp. 153-168). Montréal: Éditions Nouvelles AMS. 